\title{
宿題報告
}

\section{Interpleural Analgesia}

\author{
山本 健*
}

\section{I はじめに}

胸腔内局麻薬注入法 ${ }^{1)}$ は, 胆摘術, 腎臓手術あ るいは乳腺手術など,一側の非開胸手術の術後 鎮痛法としてまず使用され，さらに開胸手術の 術後疼痛やペインクリニックにも応用が試みら れている。同法の名称としては, interpleural, intrapleural の両者が用いられてきたが，壁側 胸膜と藏側胸膜の間に局麻薬が注入されること から，最近では“interpleural ”にほほ統一され ている2). 本報告では，胸腔内局麻薬注入法を Interpleural Analgesia と呼び，以下 IPA と略 す.

\section{Interpleural Analgesia の実施手技}

ヒトの壁側・臓側胸膜間の距離は $8 \sim 12$ ミク ロンにすぎず, 極めて狭いすきまである3).この すきまをぬって肺実質を傷つけることなくチュ ーブを挿入するには，臓側胸膜に対して接線方 向から針を刺入する必要がある. 穿刺針として は，肺実質を針の先端で押しのけながら胸腔穿 刺ができるという点から, Tuohy 針が適してい る. 我々は穿刺器具として, ポーテックス社製 ミニパックシステム-2（カテーテルの外径1.1

*金沢大学医学部麻酔・蘇生学教室 $\mathrm{mm}$, Tuohy 針の外径 $1.6 \mathrm{~mm}$, バクテリアフィルタ 一つき）を使用した。

胸腔穿刺ならびにチュービングは Raiestad らの方法 ${ }^{4,5)}$ に従い, 全身麻酔の導入後, 手術に 先立って経皮的に行った. 穿刺時の体位は手術 側を上にした側臥位とし，後腋窩線上で第 8 ま たは第 9 肋間を穿刺部位とした。

Tuohy 針は穿刺助間の下位助骨上緑から刺 入し，皮膚と約 30 度の角度を保って頭側へ向け て進めた．針のベベルは常に皮膚側に向け，臟 側胸膜を傷つけぬように努めた．針先が壁側胸 膜を穿刺する寸前に用手換気を止め，呼気相て 胸腔を穿刺した。針先が胸腔内に達したことは, 内壁を濡らしたガラス製注射器の内筒が，胸腔 内の陰圧のために引き込まれることによって確 認したが，陰圧が明らかでないものでは抵抗消 失法によった。

胸腔内に注入する局麻薬は，アドレナリンを 含まない $0.5 \%$ ブピバカイン $20 \mathrm{~m} \ell に$ 統一した.ま た，手術中の体位にかかわらず，局麻薬注入時 には体位を仰臥位に戻すとともに，注入後15分 間は頭側を約15度下げた体位を維持した。

経皮的に胸腔内チュービングを実施した30例 のうち，陰圧によって容易に胸腔内穿刺を確認 できたものは $80 \%$ (24/30例)，抵抗消失法によ ったものは $20 \%$ ( $6 / 30$ 例) であった。 また，本 
法を実施する上で最も注意を要する気胸の発生 は, 30 例中 1 例のみにみられ，しかも術後短時 間で消失したことから，臓側胸膜の損傷による ものではなく，チューブを挿入する際に，穿刺 針を通して空気が胸腔に吸い込まれたものと考 えられる.Symreng ら ${ }^{6)}$ は Tuohy 針よりも先端 が鋭い Hustead 針を用い, かつ針先を尾側に向 けて経皮的に胸腔内チュービングを行ったとこ ろ，21例中 7 例でチューブ先端が肺実質内に刺 入され，2例に緊張性気胸を認めたと述べてい る. 使用する針の種類と穿刺方法によっては, 臓側胸膜や肺実質の損傷が起こり得ることを念 頭におく必要があろう。

\section{Interpleural Analgesia による皮属知覚の変化}

これまでに報告されているIPAによる皮膚 知覚の変化は，そのほとんどが手術直後に調べ られたものであり，全身麻酔薬の残存効果や， 手術による影響が無視できない。我々は，開胸 手術の予定患者 5 名を対象として手術前日に局 麻下に胸腔内チューブを刺入留置し, $0.5 \%$ ブピ バカイン $20 \mathrm{~m} \ell を$ 注入して皮膚知覚の変化を調 べ，同時に皮膚温の変化をサーモグラフィによ って観察した。その結果, 注入側の肋間神経領 域の知覚鈍麻は注入後 5 分の時点ですでに認め られたが, 無痛域は注入後 20 分以降でなければ 認められなかった。

無痛域の範囲は, 5 例中 3 例では注入側の 2 ないし 3 分節の肋間神経領域に認められ，1例 では注入側の第 2 から第12肋間神経領域に及ぶ 広い範囲に無痛域が認められた。この症例では, 反対側の同じ肋間神経領域にも知覚鈍麻が出現 した. 残りの 1 例では胸水の貯留があったため か，局麻薬注入による無痛域は認められなかっ た（表 1).

\section{表 1 局麻下胸腔穿刺例における皮庙知覚の変化}

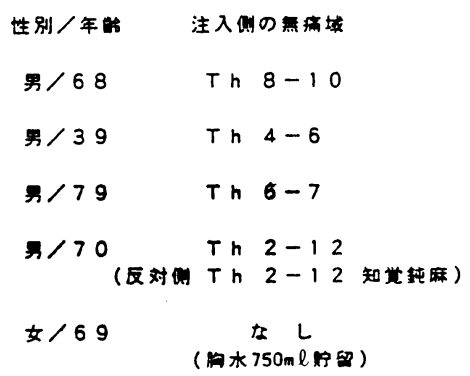

胸腹部の皮膚温は局麻注入 30 分後まで観察し たが，注入側，反対側ともに明らかな変化を認 めなかった，血圧・脈拍は，全経過を通して変 化がなかった。なお，これらの 5 症例は，翌日 の開胸術中に胸腔内チューブを直視下に観察 し，正しい位置にあることを確認している。

IPA による皮膚知覚の変化について, Seltzer ら ${ }^{7)}$ は胆摘術症例に IPA を実施し，アドレナリ ン入り $0.5 \%$ ブピバカイン $30 \mathrm{~m} \ell を$ 注入したとこ ろ，麻酔域は最大でも Th 4-11，多くはTh 5 -10であったと報告している，また，van Kleef $ら^{8)}$ は胆摘術あるいは腎蔵手術を受けた 12 例に

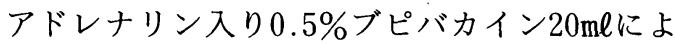
る IPA を実施し，無痛域は 2-9 皮膚分節とバ ラつきがあったとしている。いずれも，我々の 今回の知見に類似した成績であり，広範囲の皮 膚の無痛域の出現はむしろまれと考えられる.

\section{IV 胸腔内に注入された薬液の分布}

胆摘術症例 5 例を対象として, 麻酔覚醒後, 仰臥位で CT スキャンを実施した。CT スキャ ンに先立って,イオパミドール ${ }^{\mathrm{TM}} 10 \mathrm{~m} \ell と 0.5 \% フ ゙$ ピバカイン $10 \mathrm{~m} \ell の$ 等量混合液を胸腔内に注入し た．穿刺側は，胆摘症例であるのですべて右側 


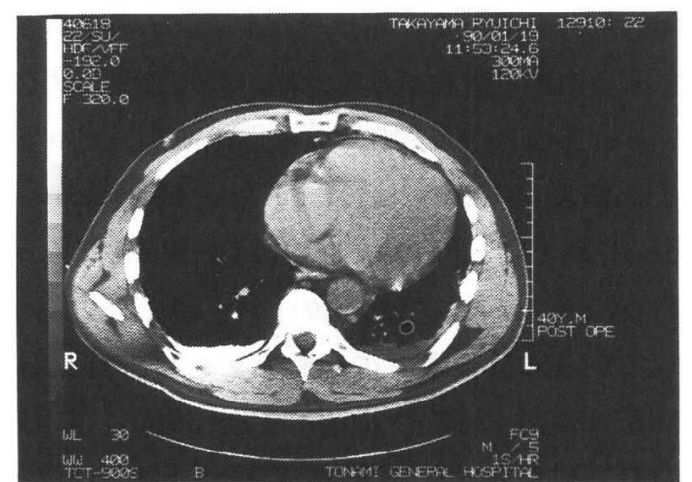

図 1 胸腔内の薬液分布, 40歳男性 造影剂の分布が最も厚い部分のスライスを示す.第 8 胸椎椎体の高さに相当する.注入側の胸腔背面に造影 剤の貯留を認める。

である。その結果, 造影剤は仰臥位で最も低い 部位である胸腔背面に貯留し，そこから胸腔の 外側面と縦隔に向かって半月状に広がった. 頭 -尾側への造影剂の広がりは,第 5 胸椎から第 11 胸椎椎体の高さに分布するものが大部分であっ た. 胸腔背面に分布する造影剤の厚さが最大と なる部位は, 第 7 ないし第10胸椎椎体の高さで あった，胸腔外や脊柱管内への造影剂の分布は 1 例も認められなかった。代表的な所見を図 1 , 2 に示す。表 2 は，これら 5 例の CT スキャン の所見と, IPAによる無痛域を対比したもので ある. 無痛域は, 注入側の第 7 ないし第 8 肋間 神経の支配領域を中心に，1ないし 6 分節にわ たって認められた。造影剤が最も厚く分布する 椎体の高さと無痛域は, ほほ一致した。また, 1 例には注入側の Horner 症候群が，2 例には 反対側にも知覚鈍麻が認められた。 反対側の知 覚鈍麻の範囲は, 注入側の無痛域が認められた 領域と同一であった. なお, 表 2 の中で無痛域 の記載がない 2 例は, 医師側の事情のため調査 ができなかったものである.

CTを用いた胸腔内の薬液分布は, Brismar

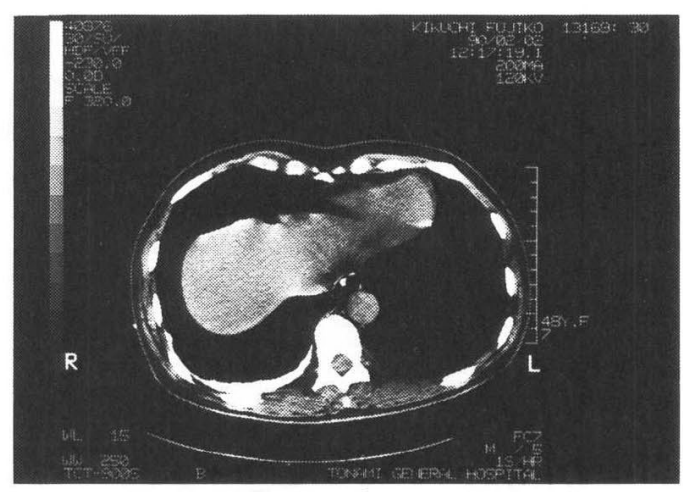

図 2 胸腔内の薬液分布, 48歳女性

図 1 と同じく造影剂の分布が最も厚い部分のスライ スを示す.第10胸椎椎体の高さに相当する.本例では, 胸腔背面から椎体側面まで造影殽が分布する.

ら゙および Stroemskag ら ${ }^{10)}$ が報告しており， 特に Stroemskag は, 仰臥位での頭-尾側の広 がりはTh 3-L 1 であり, 造影剤は, 胸腔外側 に比べ, 縦隔側により厚く分布したとしている. 我々の得た結果からは, 頭側への造影剂の分布 がTh 3 に達する例はまれであり, 縦隔側と胸 腔外側とで造影剂の分布が異なるという所見 は, 5 例中の 1 例での数スライスを除いて認め られなかった。

\section{$\mathrm{V}$ 局麻薬の血中濃度}

ブピバカインの血中中毒レベルは，成人では

表 $2 \mathrm{CT}$ スキャンの所見と皮庯知覚の変化

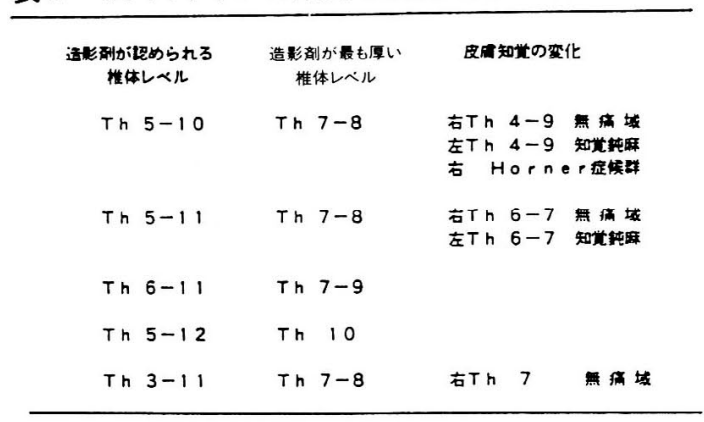




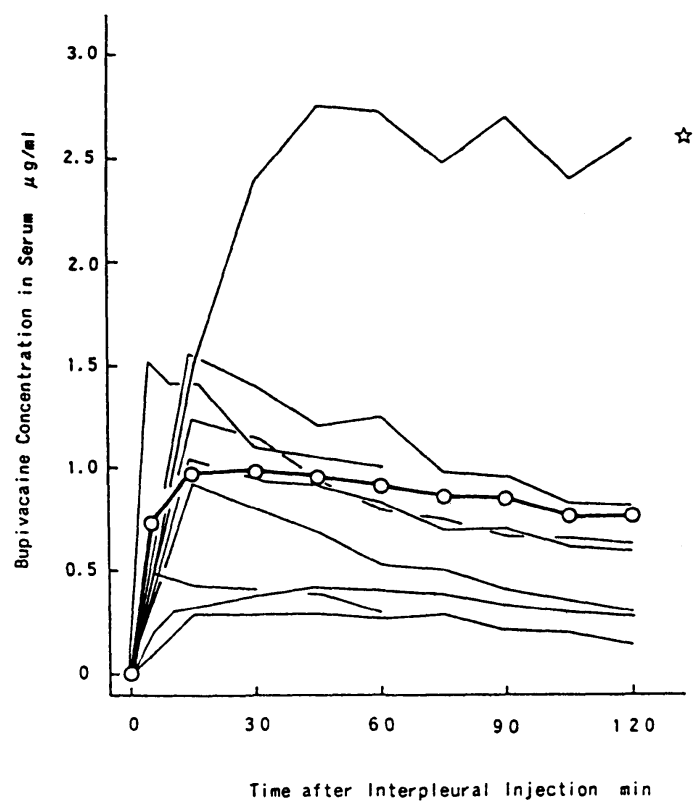

図 3 開胸術における動脈血血清中ブピバカイン 濃度 $(n=9)$

$2.3 \sim 4 \mu \mathrm{g} / \mathrm{m} \ell$, 小児では $4 \sim 7 \mu \mathrm{g} / \mathrm{m} \ell$ といわれ ている.我々は開胸術症例については血中なら びに胸腔ドレン排液中の局麻薬濃度を, また非 開胸手術である腎臓手術症例では血中局麻薬濃 度のみを，それぞれ測定した。血中濃度測定に は動脈血血清を用い.ブピバカインの定量は高 速液体クロマトグラフィによった。

開胸術症例14例中 9 例を対象として, 動脈血 血清中のブピバカイン濃度を局麻薬注入後 120 分間にわたって測定し, 胸腔ドレン排液中のブ ピバカイン量については, 注入後 60 分の時点で 測定した. 図 3 は, 動脈血血清中ブピバカイン 濃度の推移である．太い実線は，9例の平均濃 度を示す。 9 例中 8 例では, 血清ブピバカイン 濃度が中毒レベルに達したものはなかったが, 星印をつけた 1 例では, 最高血清濃度 $2.75 \mu \mathrm{g} /$ $\mathrm{m} \ell$ 示した。この症例は壁側胸膜を広範囲に切
除したものであり，ブピバカインが筋肉層から 急速に血中に吸収されたため，高い血清濃度を 示したものと考えられる.9例の血清ブピバカ イン濃度の $\mathrm{Cmax}$ は $1.1 \pm 0.3 \mu \mathrm{g} / \mathrm{m} \ell$ （mean士 SEM, 以下同じ) Tmax は19.4 $15.0 \mathrm{~min}$ であっ た(図 3 )。また，ブピバカインを胸腔内に注入 してから60分後までの胸腔ドレン排液総量は $163.9 \pm 31.7 \mathrm{~m} \ell$ (range 80 390), 排液 中のブピバカイン総量は $14.0 \pm 3.5 \mathrm{mg}$ (range 1.9〜32.9)であり,ブピバカインの総注入量 100 $\mathrm{mg}$ に対して, 平均 $14 \%$ が流出した. したがって, 胸腔ドレンの存在は, 胸腔内におけるブピバカ インの薬物動態に大きな影響を与えないものと 考えられる。

次に, 非開胸例である腎藏手術に IPA を行っ た11例中 5 例について，動脈血血清中のブピバ カイン濃度を 4 時間にわたって測定した（図 4 ). 太い実線は, 図 3 と同じく平均值を示す. 動脈血血清中のブピバカイン濃度の変化は個人 差が大きく， 2 例では $3 \mu \mathrm{g} / \mathrm{m} \ell に$ 達した，腎臓 手術例での T max は注入から10２0分, Cmax

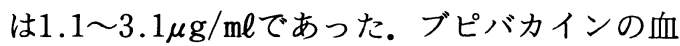
中濃度と鎮痛作用の持続時間の間には一定の関 係が認められなかった。

Brismar ${ }^{9}$ は非開胸手術にIPAを実施し, $0.5 \%$ ブピバカイン $20 \mathrm{~m} \ell を$ 注入した際の静脈血 槳中ブピバカイン濃度は $\mathrm{Cmax}=0.8 \mu \mathrm{g} / \mathrm{m} \ell$; $\mathrm{T} \max =20 \sim 30$ 分であったが，血中濃度には個 人差が大きく, 1 例では $1.7 \mu \mathrm{g} / \mathrm{m} \ell$ の高濃度が検 出されたと報告している. Seltzer らブ，アド

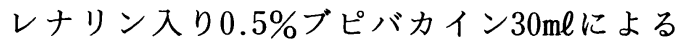
IPA での静脈血清中ブピバカイン濃度は, $\mathrm{Cmax}=2.07 \pm 0.58 \mu \mathrm{g} / \mathrm{m} \ell$ (range $1.1 \sim 3.3$ ), Tmax は20.5 $18.3 \mathrm{~min}$ と報告している。また， van Kleef ${ }^{11)}$ は胆摘術あるいは腎臓手術を受け 


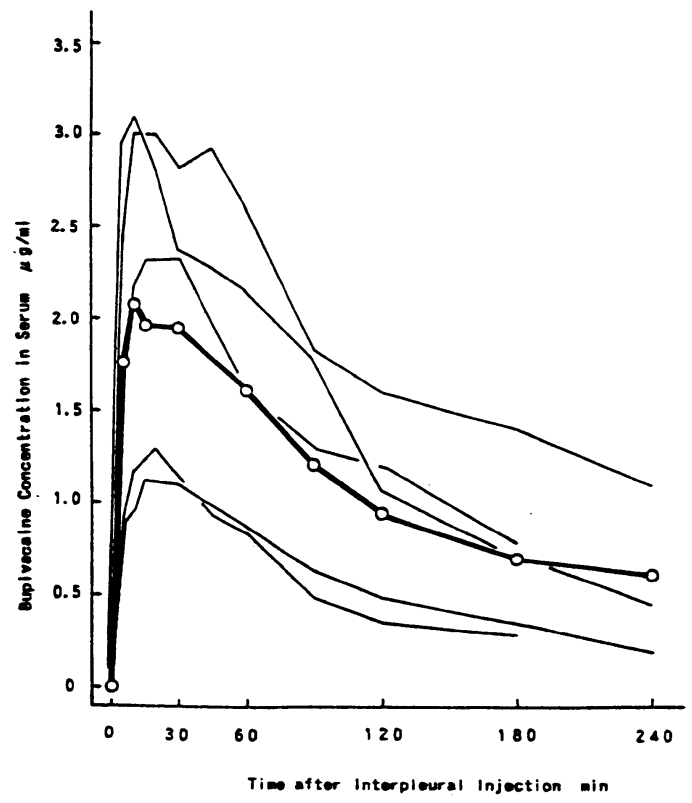

図 4 非開胸術における動脈血血清中プピバカイ ン濃度 $(n=5)$

た 12 例に,アドレナリン入り $0.5 \%$ ブピバカイン

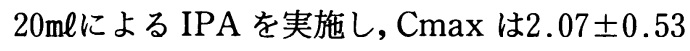

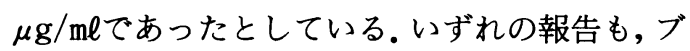
ピバカインの血中濃度はかなり高く, 中毒レベ ルに近い例も認められる点で一致している。

海外ではアドレナリン入りのブピバカインを 使用することが多いが, Denson ら ${ }^{12) な ら ひ ゙ に ~}$ Gin $ら^{13)}$ は, アドレナリン添加によって薬物動 力学的なパラメータは変化しないが, 最高血槳 中濃度は有意に低く推移したと報告している。

一方, アドレナリンによる高血圧, 頻脈などの 副作用も報告されており，アドレナリンの添加 には問題が残る。
VI 術後鎮痛法としての Interpleural Analgesia の評価

\section{1. 開胸術症例に対する術後鎮痛効果}

肋骨に面した壁側胸膜は肋間神経によって支 配され,一方, 藏側胸膜は肺神経叢から自律神 経の支配を受けるが, 痛覚や触覚などは存在し ない ${ }^{14)}$. したがって開胸術後の疼痛は, 壁側胸膜 に分布する肋間神経を広範囲に遮断することに よって防止できる.

開胸術14例を対象として, 手術終了後, 患者 が疼痛を訴えた時点で患者の頭側を約15度低く

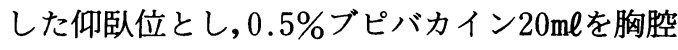
内に注入した．開胸術では注入された局麻薬が 胸腔ドレンから流出するのを防ぐため，局麻薬 の注入直前から 20 分間は胸腔ドレンをウォータ ーシールとした。注入後 20 分経過しても疼痛が 軽減しない場合には, ブトルファノール $2 \mathrm{mg} を$ 筋注した。対照群として，別の開胸術症例10例 に術後鎮痛薬としてブトルファノール $2 \mathrm{mg}$ のみ を筋注し, IPA 群と比較した。

その結果, IPA のみで十分な鎮痛が得られた ものは14例中 3 例のみであり, 残りの11例では ブトルファノール筋注を併用したが，その鎮痛 効果の持続時間はブトルファノールのみを筋注 した群に比べて有意差がなかった。

IPA の効果が不十分な原因としては, CT ス キャンの所見からも明らかなように，上部胸腔 には局麻楽が到達しにくいことに加えて, 手術 後の出血や組織の浮腫, 肺切除後の死腔の存在 などにより局麻薬の広がりが妨げられることが 最も大きいと考えられる，局麻楽が胸腔ドレン から胸腔外に流出することは事実であるが, 先 に述べたように，その量は総投与量の平均 $14 \%$ にすぎず，これによって鎮痛効果が不十分にな 
るとは考えにくい，以上，我々の経験からは， IPA は開胸手術後の鎮痛方法として有用とは 認められなかった。

開胸術後の鎮痛方法としての IPA の評価は, 研究者によって正反対の結果が報告されてい る.すなわち, Kambam ら ${ }^{15)}$, Reiestad $~^{16), 17),}$ McIlvaine $~^{18), 19)}$ は, IPA は開胸術後の鎮痛法 として有効であると報告している.一方, IPA の効果が短いこと，あるいは鎮痛作用が不十分 であることから，開胸術後鎮痛法としての有用 性には否定的な見解も多く20) 24), 開胸術への IPA の効果については，末だ決着をみていない のが現状である。

\section{2. 腎臓手術・胆毫摘出術症例に対する術後鎮 痛効果}

片側の腎臓手術を受けた成人患者11例に, 術 後 IPA を実施した. $0.5 \%$ ブピバカイン $20 \mathrm{~m} \ell の$ 注入による鎮痛効果の発現には15～20分間を要 した。効果の持続時間は425.5 $471 \mathrm{~min}$ (range60〜 720) であり, 平均約 7 時間の効果持 続時間が得られた．副作用として，1例に注入 後10分の時点で高度の血圧低下が認められ, 昇 圧薬の静脈内投与を必要とした。この症例は, ブピバカイン血中濃度が中毒レベルに達してい たものであった.

肋骨弓下切開で胆囊摘出術を受けた成人症例 5 例では，CT スキャンを撮影するために初回

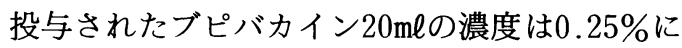
希釈されたが, 効果持続時間は $300 \pm 93 \mathrm{~min}$ (range60〜 540) であり，0.5\%ブピバカイン 20 $\mathrm{m} \ell$ を投与した腎臓手術例との間に有意な差は認 められなかった。

従来広く用いられている硬膜外モルヒネ注入 法との比較を行う目的で, 今回実施した腎臓手 術ならびに胆摘術での IPA16例の効果と, 胆摘
術後の硬膜外モルヒネ注入法15例の効果を比較 した. モルヒネの注入量は $4.3 \pm 0.2 \mathrm{mg}$ (range 3 $\sim 6)$, 鎮痛効果持続時間 は $823 \pm 144 \mathrm{~min}$ (range $45 \mathrm{~min} \sim 24 \mathrm{hrs}$ ) であり, IPA の効果時間 $386 \pm 57 \mathrm{~min}$ (range60〜 720) に比べて有意に長 かった. 硬膜外モルヒネ注入法の副作用として， 全身のかゆみ 6 例, 嘔気 1 例, 呼吸抑制 1 例が 認められた。

\section{Horner 症候群と反対側の知覚鈍麻}

注入側の Horner 症候群が30例中 1 例に認め られた. Horner 症候群が IPA に合併すること

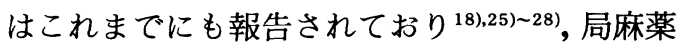
が壁側胸膜を越えて胸腔外に拡散することの有 力な証拠となっている. また，反対側の知覚鈍 麻域が30例中 6 例に認められた。これまでには このような反対側への効果を報告したものはな いが，注入側の無痛域と反対側の知覚鈍麻域の 高さが一致することから，局麻薬が胸腔から胸 腔外へ拡散し，硬膜外腔を介して反対側の肋間 神経に作用するものと考えざるを得ない.

\section{VIII ま と め}

(1) Interpleural Analgesia の手技は容易であ り，30例中 24 例 $(80 \%)$ の症例では，陰圧によ って胸腔内穿刺を確認できた。気胸は 30 例中 1 例のみに認められた。

(2) Interpleural Analgesiaによる皮膚の知覚 鈍麻は, 局麻薬の注入後 5 分の時点ですでに認 められたが，無痛域の出現には局麻薬注入から 20分以上を要する.

無痛域の範囲は中・下位肋間神経の 2 ないし 3 分節, 最大でも 6 分節に止まることが多く, 広範な無痛域の出現はむしろまれである。

（3）循環系ならびに皮膚温には変化がみられな 
かった。

(4) 胸腔内に注入された薬液は, 胸腔背面の最も 低い部位に貯留し，さらにそこから胸腔外側と 綐隔に向かって広がる．頭側への造影剤の広が りは第 5 胸椎椎体の高さを越えることはまれで ある。

（5）注入側の皮虐の無痛域は, 造影剤が最も厚く 分布する椎体の高さとほほ一致し, 胸腔内の薬 液分布と皮膚知覚の変化は密接に関連すること が確かめられた。

(6) CT スキャンからは, 胸腔外や脊柱管内への 造影剤の分布は認められなかった。

（7）開胸手術の術後鎮痛法としては, Interpleural Analgesiaは効果が不確実であり,すすめら れない.

（8）腎蔵あるいは胆哓などの非開胸手術例にお ける Interpleural Analgesia の効果は良好で, その持続時間は平均 7 時間であった. 効果持続 時間に関しては, ブピバカイン濃度が $0.5 \%$, $0.25 \%$ のい゙れであっても，有意の差はないよ うである。

（9）動脈血血清中のブピバカイン濃度は個人差 が大きく, 中毒レベルに達する例も認められた。 これより, 日本人の成人症例には， $0.25 \%$ ブピ バカインが適すると考えられる。

(10) 注入側の Horner 症候群が30例中 1 例に認 められた．胸腔内に注入された局麻薬が，壁側 胸膜を越えて胸腔外に拡散することの有力な証 拠と考えられる。

(11) 反対側の知覚鈍麻が30例中 6 例に認められ た. 注入側の無痛域と反対側の知覚鈍麻域の高 さが一致することから，硬膜外腔を介する作用 と考えられる。

(12) Interpleural Analgesia と硬膜外モルヒネ 注入法の比較では, 効果時間の長い点と, 正中
線を越えて両側に効果を示す点が硬膜外モルヒ ネの利点である。

一方, Interpleural Analgesia は, 手技が簡単 で，重篤な合併症を起こす危険がほとんどない 点に特徴があり, 腎臓や胆囊手術といった, 一 側の上腹部手術後の鎮痛法として適している.

稿を終えるにあたり，発表の機会を賜った第 10回日本臨床麻酔学会会長 故田中亮教授に心 から謝意を表します。また，研究の遂行にご協 力をいただいた金沢大学医学部麻酔・蘇生学教 室；村上誠一教授，李文志先生，研波総合病院 麻酔科；生垣正先生，遠山芳子先生および示野 勝巳先生に感謝いたします。

\section{参考文献}

1) Kvalheim L, Reiestad F : Interpleural catheter in the management of postoperative pain. Anesthesiolgy 61 ( $3 \mathrm{~A}): \mathrm{A} 231,1984$

2 ) Covino BG : Interpleural regional analgesia (Editorial). Anesth Analg $67: 427 \sim 429,1988$

3 ) Camporesi EM : Intrapleural analgesia : A new technique (Editorial) . Cardiothoracic Anesthesia 3 : $137 \sim 138,1989$

4) Reiestad F,Stroemskag KE : Intrapleural catheter in the management of postoperative pain-A preliminary report. Regional Anesthesia $11: 89 \sim 91,1986$

5 ) Rocco A, Reiestad F, Gudman J, et al.: Intrapleural administration of local anaesthetics for pain relief in patients with multiple rib fractures -preliminary report. Regional Anesthesia 12:10 14, 1986

6 ) Symreng T, Gomez MN, Johnson B, et al.: Intrapleural Bupivacaine-Technical Considerations and Intraoperative Use. Cardiothoracic Anesthesia 3 : 139 143, 1989

7 ) Seltzer JL, Larijani GE, Goldberg ME, et al.: Intrapleural bupivacaine-a kinetic and dynamic evaluation. Anesthesiology $67: 789 \sim 800,1987$

8 ) van Kleef JW, Burm AGL, Vletter AA : Single-Dose Interpleural Versus Intercostal blockade : Nerve Block Characteristics and Plasma Concentration Pro files after administration of $0.5 \%$ Bupivacaine with Epinephrine. Anesth Analg 70:484 488, 1990

9 ) Brismar B, Pettersson N, Tokics L, et al.: Postoper- 
ative analgesia with intrapleural administration of bupivacaine - adrenaline. Acta Anaesth Scand 31 : 515 520, 1987

10) Stroemskag KE, Hauge O, Steen PA : Distribution of local anesthetics injected into the interpleural space, studied by computerized tomography. Acta Anaesth Scand $34: 323 \sim 326,1990$

11) van Kleef JW, Burm AGL, Vletter AA : Single-dose interpleural versus intercostal blockade : Nerve block characteristics and plasma concentration profiles after administration of $0.5 \%$ bupivacaine with epinephrine. Anesth Analg $70: 484 \sim 488,1990$

12) Denson D, Sehlhorst CS, Schultz REG, et al.: Pharmacokinetics of intrapleural bupivacaine : effects of epinephrine. Regional Anesthesia (Supple) 13:47, 1988

13) Gin T, Chan K, Kan AF, et al.: Effect of adrenaline on venous plasma concentrations of bupivacaine after interpleural administration. Brit J Anaesth 64 : $662 \sim 666,1990$

14) Snell RS, Katz J : Clinical Anatomy for anesthesiologists. Appleton \& Lange, California, 1988, p46

15) Kambam JR, Handte RE, Flanagan J, et al: Intrapleural anesthesia for post thoracotomy pain relief. Anesth Anålg 66 (2S) : S90, 1987

16) Reiestad F, Stroemskag KE, Heen L : Intrapleural catheter for analgesia after thoracotomy in adult patients. Acta Anaesth Scand 31 (Supple 86) : No 237, 1987

17) Reiestad F, Stroemskag KE, Rocco A, et al.: Intrapleural catheter for analgesia after thoracotomy in adult patients. 9th WFSA, Abstract A0740, 1988

18) Mcllvaine WB, Knox RF, Fennessey PV, et al.: Continuous infusion of bupivacaine via intrapleural catheter for analgesia after thoracotomy in children. Anesthesiology $69: 261 \sim 264,1988$

19) Mcllvaine $W$, Chang JHT, Jones $M$ : The effective use of intrapleural bupivacaine for analgesia after thoracic and subcostal incisions in children. J Pediatr Surg $23: 1184 \sim 1187,1988$

20) Symreng T, Gomez MN, Rossi N : Intrapleural bupivacaine $\mathrm{v}$ saline after thoracotomy-Effects on pain and lung function $-\mathrm{A}$ double-blind study. Cardiothoracic Anesthesia $3: 144 \sim 149,1989$

21) Rosenberg PH, Scheinin BMA, Lepantalo MJ, et al.: Continuous intrapleural infusion of bupivacaine for analgesia after thoracotomy. Anesthesiology 67 : $811 \sim 813,1987$

22) Dale $O$, Reiestad F, McIlvaine WB, et al.: The experts opine : Interpleural analgesia : advantages and limita tions in comparison to thoracic epidural analgesia : Survey of Aesthesiology $33: 188 \sim 194,1989$

23) El-Baz N, Faber LP : Intrapleural infusion of local anesthetic : A word of caution. Anesthesiology 68 : $809 \sim 810,1988$

24) Scheinin B, Lindgren $L$, Rosenberg PH : Treatment of post-thoracotomy pain with intermittent instillations of intrapleural bupivacaine. Acta Anaesth Scand 33 : $156 \sim 159,1989$

25) Sihota MK, Holmblad BR : Horner's syndrome after intrapleural anesthesia with bupivacaine for postherpetic neuralgia. Acta Anasth Scand $32: 593 \sim 594$, 1988

26) Sihota MK, Ikuta PT, Holmblad BR, et al.: Successful pain management of chronic pancreatitis and post herpetic neuralgia with intrapleural technique. Regional Anaesthesia 13 (Supple 2) : 40, 1988

27) Parkinson SK, Mueller JB, Rich TJ, et al.: Ulilateral Horner's syndrome associated with interpleural catheter injection of local anesthetic. Anesth Analg 68 : $61 \sim 62,1989$

28) Reiestad F, McIlvaine WB, Kvalheim L, et al.: Interpleural Analgesia in treatment of upper extremity reflex sympathetic dystrophy. Anesth Analg 69 : $671 \sim 673,1989$

\author{
著者連絡先 山本 健 \\ 7920 石川県金沢市宝町13-1 \\ 金沢大学医学部麻酔・蘇生学教室
}

